\title{
Permian-Recent palaeogeographical and tectonic development of Anatolia: some recent contributions
}

\author{
Alastair H. F. Robertson ${ }^{1}$ - Osman Parlak $^{2}$ - Timur Ustaömer ${ }^{3}$
}

Received: 27 August 2015 / Accepted: 5 September 2015 / Published online: 16 October 2015

(C) Springer-Verlag Berlin Heidelberg 2015

The present set of 18 papers presents much new geological information, interpretation and synthesis related to the Permian-Pleistocene sedimentary, magmatic, metamorphic and structural development of Anatolia and Cyprus in their regional tectonic context (Fig. 1). Of these, 12 of the contributions were aided by financial support from the international DARIUS Programme, which was funded by a consortium of hydrocarbon companies and French research organizations. The area of research interest for the DARIUS Programme extends from Turkey and Cyprus, eastwards to central Asia. Additional sets of research papers are being published elsewhere related to the Caucasus-Black Sea and central Asian regions. The three sets of papers complement and extend the primary output of the DARIUS Programme, which is a new set of palaeogeographical maps covering the entire region for Permian to Pleistocene time.

The area covered here, Anatolia, Cyprus and adjacent areas, can be subdivided into two fundamental tectonic entities that are covered by Parts 1 and 2 of the special issue.

The first fundamental subdivision of Anatolia is the southern continental margin of Eurasia, represented by the Pontide mountain belt of northern Turkey and its eastward extension into the Caucasus. During the time period of interest here (Permian-Pleistocene), the Pontides record

Alastair H. F. Robertson

Alastair.Robertson@ed.ac.uk

1 Grant Institute, School of GeoSciences, University of Edinburgh, James Hutton Road, Edinburgh EH9 3FE, UK

2 Jeoloji Mühendisliği Bölümü, Çukurova Üniversitesi, 01330 Balcalı, Adana, Turkey

3 Jeoloji Mühendisliği Bölümü, İstanbul Üniversitesi, 34310 Avc1lar, Istanbul, Turkey active continental margin processes including subduction, accretion and arc magmatism and also collisional processes. During the Mesozoic (and probably earlier), the southern margin of Eurasia was bordered by oceanic crust known as the İzmir-Ankara-Erzincan ocean (also known as the Northern Neotethys), which records several different tectonic settings (e.g. mid-ocean ridge and above subduction zone oceanic crust). Part 1 of this special issue encompasses six papers that discuss aspects of the sedimentary, magmatic and tectonic development of the Pontides and their correlation with the Lesser Caucasus to the east.

The second fundamental subdivision of Anatolia encompasses part of the northern continental margin of Gondwana, represented by the Arabian continent in SE Turkey, together with several microcontinental units (e.g. TauridesAnatolides; Kırşehir Massif). The continental units rifted from Gondwana during the early Mesozoic opening ocean basins behind them. Oceanic crust was created in several different tectonic settings within these basins, namely midocean ridge crust, above subduction zone crust and seamount crust. During later Mesozoic to Cenozoic times, the ocean basins subducted, leading eventually to diachronous continental collisions that are still in progress today in the Eastern Mediterranean region. Twelve of the papers, making up Part 2 of the special issue, concern the sedimentary, magmatic, metamorphic and structural development of central and southern Turkey and Cyprus.

\section{Part 1: Pontides and adjacent oceanic crust}

One of the most important and widespread geological units extending across Anatolia is the Permo-Triassic Karakaya Complex. The Karakaya Complex is an accretionary prism that includes huge volumes of arc-derived volcaniclastic 
Fig. 1 Outline tectonic map of Anatolia, Cyprus and adjacent areas showing the locations of the study areas in this special issue: 1. Ustaömer et al. 2.

Maroni et al. 3. Danelian et al. 4. Hippolyte et al. 5. Varol et al. 6. Hisarli et al. 7. Robertson et al. 8. Pourteau et al. 9. Scheffler et al. (note: this paper is based on scattered outcrops throughout southern Turkey and is therefore not shown as a specific boxed area). 10. Çetinkaplan et al. 11. Nurlu et al. 12 . Akınc1 et al. 13. Poisson et al. 14. Koç et al. 15. Morris et al. 16. Robertson and Kinnaird 17. Palamakumbura et al. 18. Main et al.

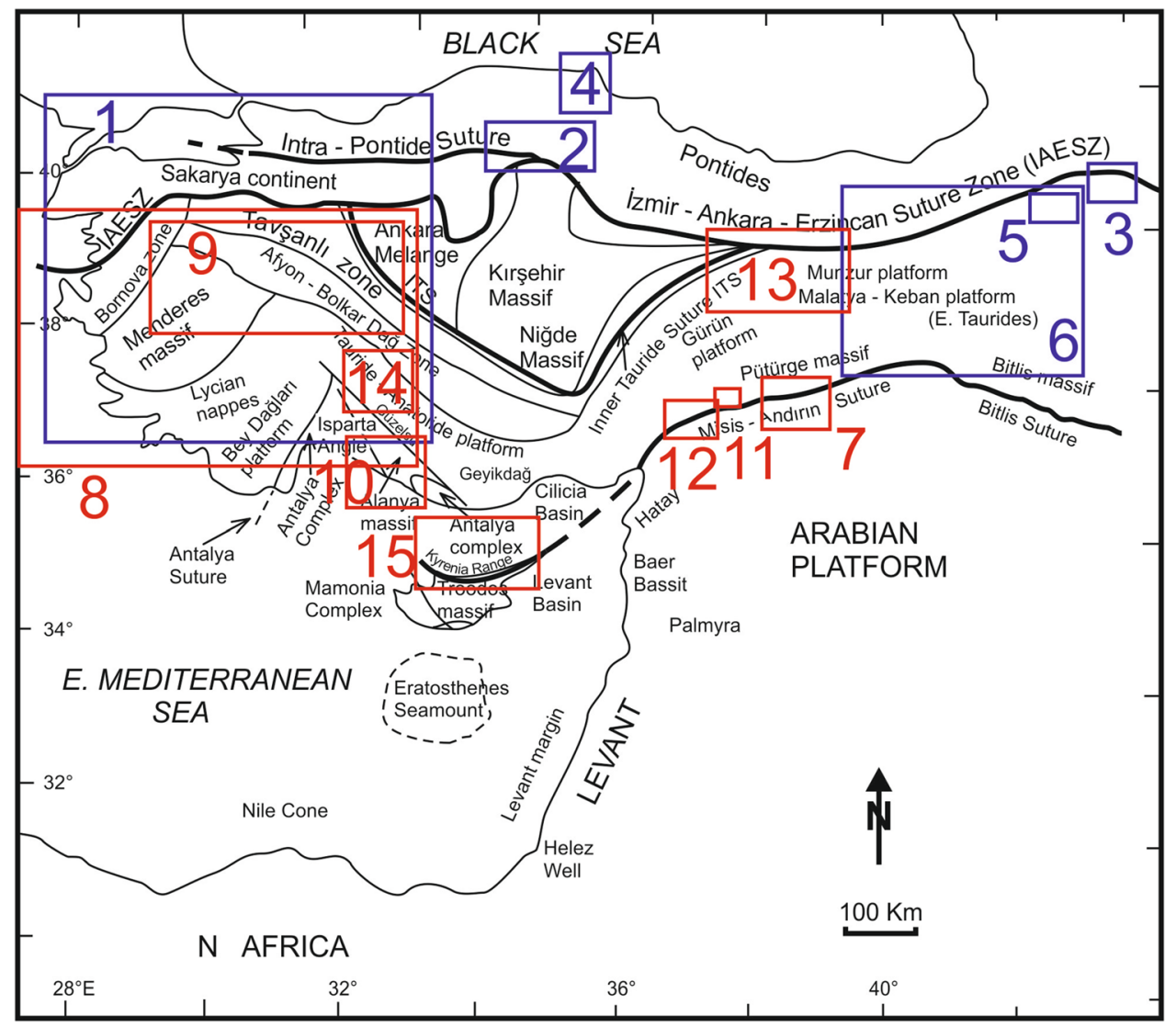

sediment. Based on $\mathrm{U}-\mathrm{Pb}$ radiometric dating and $\mathrm{Lu}-\mathrm{Hf}$ isotopic analysis, Ustaömer et al. document predominantly Carboniferous, Triassic and Devonian zircon age groups, suggesting a Late Triassic (Carnian) maximum depositional age. The authors infer that potential igneous source rocks for the Karakaya sandstones might exist in the Devonian and Carboniferous granitic rocks of the Sakarya continental unit to the north. However, Triassic granitic rocks of this unit differ significantly in Lu-Hf isotopic signature and corresponding model ages from the sandstones of the Karakaya Complex. Based on similar data from comparative units in the Pontides and Taurides-Anatolides, the authors show that the likely source region was somewhere along the southern margin of Eurasia, although the exact location remains enigmatic.

In western and central Turkey, the Pontides include a specific suture known as the Intra-Pontide suture, which has recently attracted renewed interest. Here, Sayit et al. focus on a geochemical study of meta-mafic igneous rocks from four tectonic units that are exposed along two previously little studied transects of the Intra-Pontide suture zone. The igneous chemistry is suggestive of a range of protoliths and of formation within several different oceanic tectonic settings within an overall subduction-related setting.
To the south of the Eurasian margin, the İzmir-AnkaraErzincan suture zone evolved by processes involving spreading and subduction throughout the Mesozoic. Ophiolites (subaerially exposed oceanic crust) formed during the Jurassic in both NE Turkey and the adjacent Lesser Caucasus. Danelian et al. consider one of the ophiolites of the Lesser Caucasus in northernmost Armenia from within the Sevan-Hakari suture zone. Radiolarians extracted from several sedimentary sequences associated with the ophiolitic rocks are reported to be of Mid-Jurassic to Early Cretaceous age. The Early Cretaceous sequence provides new evidence of contemporaneous subaerial volcanism, which may be related to post-ocean floor spreading, off-axis magmatism.

Northward subduction of the İzmir-Ankara-Erzincan ocean beneath the southern margin of Eurasia had a profound regional tectonic influence during later MesozoicEarly Cenozoic time. Following this theme, Hippolyte et al. present the results of a detailed structural study of the central Pontides based on the collection of a large amount to field structural kinematic measurements which they interpret in the light of structural and stratigraphical constraints. The authors interpret the central Pontides since the Early Cretaceous as a doubly vergent orogen in which the structure was largely controlled by the inversion of normal faults. ENE-trending extensional subsidence occurred from 
Aptian to Palaeocene time, during which the Black Sea is inferred to have opened as a back-arc basin, related to northward-dipping subduction of the İzmir-Ankara-Erzincan ocean to the south. A latest Albian-Coniacian interruption in basin subsidence may relate to a hiatus in steadystate subduction. Basin inversion took place during Early Eocene to Mid-Miocene time, related, the authors believe, to collision of the Tauride and Eurasian continents and the indentation of the Kurşehir continental block.

The post-collisional Cenozoic sedimentary basins associated with the İzmir-Ankara-Erzincan suture zone have so far received little attention. Here, Varol et al. provide the first modern account of the stratigraphical and sedimentological development of one such basin, which is located in the far east of Turkey. Poorly dated sediments of mostly, or entirely, Neogene age accumulated in an intermontane basin under the influence of lacustrine and fluvial processes, punctuated by a marine incursion. Climatic change exerted an important control of sediment facies and architecture.

There is ongoing debate concerning the palaeolatitudes at which the various units making up the Pontides originated and also about the rotations of crustal units related to collisional processes. Hisarlı et al. present and interpret a palaeomagnetic study of Miocene to Quaternary volcanic rocks from 100 sites within the Tethyan suture zone as a whole in eastern Turkey. Collision of the Arabian promontory as an indenter during the Mid-Miocene is seen as the driving force behind lateral extrusion and the differential rotation of five crustal blocks, with the movements largely being accommodated by strike-slip faulting. Relative stability during the Pliocene was followed by an increased rate of rotation of all of the blocks during the Quaternary.

\section{Part 2: Arabian margin, Taurides-Anatolides and Cyprus}

The Arabian margin is widely exposed in SE Turkey. The Taurides represent allochthonous continental crust, which largely escaped Late Mesozoic and younger metamorphism. In contrast, the Anatolides, further north, preserve comparable crust that was regionally metamorphosed during subduction/collision. Cyprus includes the Kyrenia Range in the north, mostly made up of continental crust and also the Troodos ophiolite to the south, which represents uplifted oceanic crust that formed by spreading above a subduction zone during the Late Cretaceous (Fig. 1).

The contribution by Robertson et al. considers new evidence of rifting and continental break-up of the southernmost Mesozoic ocean basin in the region, known as the Southern Neotethys, based on combined sedimentary, biostratigraphical and igneous chemical data. Well-exposed igneous and deep-sea sedimentary units document rifting and continental break-up during Late Triassic-Early Jurassic time. Radiolaria of Jurassic, as well as Late Triassic age, are documented and figured. The authors interpret the exposures as unusually well-exposed remnants of an original continent-ocean transition zone. They also present new evidence of proximal passive continental slope sediments and compare their overall results with contemporaneous continental margin units elsewhere in the Eastern Mediterranean region that are related to Triassic rifting and later passive margin development.

All of the contributions that follow are concerned with various aspects of ocean basin closure and continental collision in the region.

Pourteau et al. present a wide-ranging review of the available evidence of crustal convergence affecting one, or several Mesozoic ocean basins and adjacent continental units during Late Cretaceous-Early Cenozoic time, for the western Anatolia and adjacent eastern Aegean region. Three alternative interpretations are discussed for the lithospheric slab dynamics during the closure of Neotethys in this region since the Late Cretaceous. The authors discuss issues including the timing of subduction initiation, the number and location of ocean basins and the number and location of subduction zones between the Taurides and the Pontides in this region and also the possibility of slab break-off at different times. After discussing alternate tectonic models, they conclude with their favoured scenario that involves two phases of subduction of a single lithospheric slab and accretion of two continental units separated by an intra-continental basin. Such is the complexity of the region; however, that generally agreed, quantitative palinspastic reconstructions are still some way off.

An enigmatic feature of the Anatolide regional tectonic unit, which has undergone HP-LT metamorphism, is the Rosetta Marble (peak metamorphic conditions 12 kbars; $300-350{ }^{\circ} \mathrm{C}$ ), which crops out for c. $600 \mathrm{~km}$ along strike. Scheffler et al. report on the sedimentological features and metamorphic processes involved in formation of the Rosetta Marble. They document radiating calcitic rods forming rosette-like textures. The authors suggest that these textures represent pseudomorphs after selenite, which can show similar rosette-like fabrics. The rosettes are interpreted as an indication of evaporite precipitation from dense basin-flowing brines.

HP/LT metamorphic rocks, together with low-grademetamorphosed and unmetamorphosed rocks, characterize the Alanya Massif of near-coastal southern Turkey. Çetinkaplan et al. focus on the metamorphic petrology, large-scale structure and radiometric ages of some of the main units within the Alanya Massif. They demonstrate that eclogite-blueschist facies metamorphism is of Late Cretaceous age and that this was followed by greenschist 
facies, retrograde metamorphism still during the Late Cretaceous. They suggest that the Alanya rocks formed part of a rifted continental fragment that is also exposed in SE Turkey (Bitlis massif). They also infer the existence of a suture zone between the Tauride platform to the north and their Alanya-Bitlis continental unit to the south.

New evidence of arc magmatism related to subduction of the Southern Neotethys in SE Turkey is provided by Nurlu et al. Magmatic rocks in the frontal thrust sheet of the Tauride allochthon were previously assumed to be of Eocene age. However, the authors demonstrate by means of the field relations and radiometric dating that newly mapped granitic rocks in the area are of Late Cretaceous age. They can be correlated with a c. E-W-trending belt of granitic rocks further north that extends across SE Turkey. The Late Cretaceous intrusive rocks in the area studied cut basic volcanic rocks which, in the light of stratigraphical constraints, are interpreted as being no younger than Late Cretaceous in age. These volcanic rocks were previously assumed to be Eocene, necessitating a new tectonic model.

The Upper Cretaceous granitic rocks form part of a much larger assemblage of ophiolitic, sedimentary and mélange units which make up the leading edge of the Tauride allochthon. An adjacent area to that studied by Nurlu et al. exposes an excellent record of Late Cretaceous-Neogene units. From this, Akınci et al. document the subduction-accretion-collision history of the Tauride allochthon in relation to the Arabian continent to the south. The authors highlight the role of an Eocene-Oligocene sedimentary mélange unit (olistostrome), which records mass wasting of the over-riding Tauride active margin. The subsequent collisional history (Late Oligocene-Early Miocene) is documented by foreland basin development to the south.

The closure of oceanic basins was followed by the development a wide range of post-collisional basins that extend across several tectonic zones of Anatolia. Here, two such post-collisional basins are discussed.

The first example is the regional-scale Sivas Basin in central-eastern Anatolia, as discussed by Poisson et al. The authors provide new stratigraphical, sedimentary and biostratigraphical evidence of key sedimentary units within the basin. Strong structural complexity largely resulted from the presence of evaporites.

The second of the basins discussed is a relatively small basin in SW Turkey, the Yalvaç Basin, in which extensional processes played an important role in sedimentary and structural development, as discussed by Koç et al. The facies surrounding the basin were controlled by faulting, with facies grading into lacustrine deposits near the basin depocentre. The authors suggest that basin formation was influenced by an eastward-dipping subduction zone that is inferred to reach the surface along the c. N-S-trending
Aksu thrust; this is consistent with evidence from seismic topography and earthquake hypocentres.

The Kyrenia Range documents part of the former northern, active continental margin of the southern Neotethys. This segment has undergone uplift within the easternmost Mediterranean region, an area of incipient, diachronous continental collision. The probable explanation for the Plio-Pleistocene uplift of the Kyrenia relates to the collision of the overriding plate (Cyprus), with the leading edge of the North African continent to the south (Eratosthenes Seamount).

The Troodos ophiolite to the south of the Kyrenia Range has long been known to have undergone $90^{\circ}$ anticlockwise rotation during Late Cretaceous-Early Cenozoic time. Here, Morris et al. show by palaeomagnetic analysis of basaltic rocks that the eastern part of the Kyrenia Range and the Karpas Peninsula (in the far east) did not undergo this dramatic rotation. Palaeomagnetic sites further west, within the central and western Kyrenia Range did not yield viable palaeomagnetic data. However, since the Kyrenia Range is made up of laterally extensive thrust sheets, the authors suggest that the whole of the Kyrenia Range escaped major tectonic rotation. This implies that the boundary of the inferred Troodos-Hatay ophiolitic microplate was located between the Troodos Massif and the Kyrenia Range. On the other hand, the viable palaeomagnetic sites in the Karpas Peninsula indicate that c. 30 anticlockwise palaeorotation has taken place, which the authors relate to Cenozoic bending of the Kyrenia Range.

Bearing in mind that the Kyrenia Range provides an exceptional record of the former active continental margin of the southern Neotethys, Robertson and Kinnaird have carried out a structural study of the central segment of the Kyrenia Range, based on large-scale structural constraints and the collection and analysis of a large amount of outcrop-scale kinematic data, especially related to fault development. They show that the central Kyrenia Range underwent three main phases of contractional tectonics (latest Cretaceous, Early-Mid Eocene and latest Mioceneearliest Pliocene, which were followed by regional uplift. Controlling processes are suggested to include subduction, microcontinent collision and diachronous continent-continent collision.

The uplift of the Kyrenia Range, mainly during the Pleistocene, resulted in the creation of a range of marine to continental deposits. Here, Palamakumbura et al. give the first modern sedimentological description of the deposits associated with the two topographically lowest terraces. The authors present and analyse the data that were collected using a portable optically stimulated luminescence reader. The resulting luminescence profiles reveal major differences in luminescence characteristics between the two lowest terrace depositional systems, which can be 
related to sedimentary processes, provenance and age. The results show that potentially correlative terraces (based on field studies) have similar luminescence characteristics that are different from similar data sets obtained from other terrace deposits. The new results aid the mapping and correlation of terraces but cannot provide absolute age data.

Further south in Cyprus, the Troodos Massif is well documented as having undergone dramatic uplift, mostly during Pleistocene time (note that the recent lengthening of the Pleistocene at the expense of the Pliocene must be taken into account when considering previous literature). It has been hypothesized that the Troodos ophiolite was updomed essentially as a single entity, although some peripheral areas are known to have undergone differential fault-controlled movements. Accordingly, tectonic uplift has been seen as the main control of Pleistocene fluvial sedimentation around the Troodos Massif. However, alternative climatic, eustatic sea-level change and autocyclic (i.e. normal variation) processes have also been proposed. Here, Main et al. present the first detailed, integrated account of a representative fluvial catchment along the northern flank of the Troodos Massif, from its instigation to its lower reaches. The authors distinguish four main cycles of geomorphological terrace development and related deposition on the basis of satellite imagery and field observations. Each cycle begins with high-energy mass-flow deposition followed by lower-energy traction flow deposition and then soil development. The new results support the concept of tectonic uplift being the dominant control of the two older cycles [Mid-Pleistocene(?)], modified by climate changerelated effects. However, climatic change-related effects are likely to have exerted a strong, potentially dominant, control, on the two relatively younger [late PleistoceneHolocene(?)] cycles.

In summary, this set of papers is indicative of the current state of research in the region, particularly related to magmatism, metamorphism and sedimentary basin development. There is now a well-established tectonic framework for Anatolia and Cyprus, which allows future studies to be integrated into a regionally coherent tectonic picture. 